\title{
The Rabbles, the Peoples and the Crowds: a Lexical Study
}

The rabble, considered as a possible threat to the rule of law or as a group unworthy of civil rights, is a concept present in many languages, yet every word conveys a slightly different meaning, The article is an attempt to present the conceptual plurality of the rabble, in a way inspired by Cassin's Dictionary of Untranslatables. The term which may be considered as a starting point is Polish mottoch, which can be translated both as 'rabble' and as 'mob'. The content is organized according to some semantic patterns that can be observed in various languages and that can be used for further philosophical analysis. The article is neither an exhaustive presentation of the semantic variety related to the term mottoch, nor a philosophical analysis of social exclusion, but rather an attempt to show the plurality of meanings across languages and how it may affect and inspire philosophical inquiry.

Keywords: rabble, people, untranslatables, democracy, social exclusion 
The rabble, understood as a possible threat to the rule of law or as a group unworthy of civil rights, is a concept present in most European languages, yet every word conveys a slightly different meaning, which may be called an untranslatable rest, as in Jacques Derrida's philosophy and most recently in Barbara Cassin's work. It is precisely the framework proposed by Cassin in her Dictionary of Untranslatables (2014) which will serve as reference for this study. Each term will be thus considered as an untranslatable and the representations of the rabble will be presented according to some patterns that can be observed among the analyzed terms. Of course, these constellations are just a part of the plurality of meanings and contexts and, just like with star constellations, the patterns proposed are by no means necessary connections. The study, like the Intraduisibles themselves, is not an ergon, a complete work, but rather an attempt to join the energeiai, energies of the languages (Cassin 2014), and follow their paths in order to discover the plurality of meanings. Each path leads to new constellations and could be continued in a "never-ending process" of untranslatability (Sigov 2014). Since the mother tongue of the author is Polish, it is the term mottoch that served as a starting point and could be used as the key untranslatable organizing the other words, much like French words in the Dictionary of Untranslatables are used to present a variety of meanings to be found across different languages and philosophies.

\section{The rabble is the people}

Many of us view the rabble and civil society as opposed, and only consider the latter to be a valid subject of democracy. The rabble is not the people, or at least not its proper form. We owe the opposition between the rabble (plêthos) and the people (dêmos) to Xenophon (Cassin, Crépon and Moatti 2014, 760), or rather to the unknown author who wrote The Constitution of the Athenians in the late $5^{\text {th }}$ century B.C (Mattingly 1997, 352). About a century later Aristotle uses the term democratia to describe a deviated form of the government "by the many." The proper form of this kind of government is called just politeia, without any special name. However, when describing the city, Aristotle (unlike Plato) sees it not as a necessarily hierarchical structure, but as a multitude "made up of many parts" and uses the word plêthos instead of dêmos. According to Cassin, one can say that in spite of calling it a "deviation," Aristotle subtly praises the rule of the "mass of citizens" in his Politics (Cassin, Crépon and Moatti 2014, 761). 
A similar confusion applies to the Latin populus and plebs. First of all, populus could derive from the same Indo-European root as plêthos, but its original meaning was military - it designated the infantrymen. Therefore, plebs was initially used to describe the citizens "outside the legions" - also known as the proletarii. Gradually, the term started to designate "the common people" or "the poor" and became equivalent to multitude, turba or vulgus, often accompanied by adjectives like "uneducated" or "ignorant." So plebs becomes the equivalent of Greek plêthos, but sometimes the plebe is referred to as populus. As for the Greek vocabulary of the time, the rise of Roman Empire and the diminished role of the people prompted Dion Cassius to use the word demos for "crowd" or "rabble." Also the French word peuple and the English people could mean both "the body of citizens" and a "mass of outcasts" (Cassin, Crépon and Moatti 2014, 752, 762-763).

Looking at this ancient vocabulary, one can easily observe that none of the words described above are terms in the strict sense. All of them refer to more or less the same designate. What changes is the political vision, not the social reality. All of the terms can be used to include or exclude from power, depending on the author's personal viewpoint or the dominant ideology. The rabble is the people as long as the author values democracy, and the people becomes the rabble when it is seen as a threat to those in power. The same dynamics can be observed even today. No matter how noble the term applied to describe the subject of democracy, it can always be easily used to deride the people in question. A blatant example is provided by today's Poland. The right-wing government started using the Schmittian term suweren (sovereign) to describe the people in its propaganda, thus emphasizing its own popular legitimacy. This is probably the most dignified and majestic way of speaking about the citizens in the Polish language, but it was nevertheless ridiculed by the opposition and, due to ironic usage, now very often appears as a synonym of "uneducated masses." In arguably the most important opposition newspaper, Gazeta Wyborcza, we can read that "the sovereign keeps away from books" (Smoleński 2019), that it is unlawful (Kuczok 2019) and that the protagonists of the book Prymityw (The Primitive), that is, hooligans, eager to fight and with questionable morals, are precisely suwereni (sovereigns) (Nogaś and Kołodziejczyk 2019). These are just three examples that appear in texts published only in September and October 2019. An even more pejorative view can be found in the comments sections. When it comes to depreciating the rabble, language can evolve in no time.

The rise of Roman Empire and the diminished role of the people prompted Dion Cassius to use the word demos for "crowd" or "rabble." Also the French word peuple and the English people could mean both "the body of citizens" and a "mass of outcasts". 


\section{Pöbel and the "Luxury-Rabble"}

One can see the same movement in the etymology of the German word Pöbel, which comes from the Latin populus, via the Old French pueble, poblo (Dudenredaktion 2019), but today is one of the equivalents of the 'rabble'. For example, the term appears in Hegel's philosophy of right as a consequence of income inequality within society:

"When the standard of living of a large mass of people falls below a certain subsistence level - a level regulated automatically as the one necessary for a member of the society - and when there is a consequent loss of the sense of right and wrong, of honesty and the self-respect which makes a man insist on maintaining himself by his own work and effort, the result is the creation of a rabble of paupers. At the same time this brings with it, at the other end of the social scale, conditions which greatly facilitate the concentration of disproportionate wealth in a few hands." (Hegel 2008, 221)

Stephen Houlgate translates Pöbel as "rabble of paupers," which stresses the economic aspect of the phenomenon. It is probably also worth mentioning that some authors quote this paragraph without the last sentence, as if the creation of the rabble did not have its counterpart in the excessive wealth of the most fortunate (Luther 2009, 351; Airaksinen 1985,45$)$.

That the rabble and the elites are two symptoms of the same pheno-

Just like Hegel, Arendt sees the mob as a "by-product of capitalist production," which creates both "superfluous wealth" and the "human debris eliminated permanently from producing society". menon is one of the main hypotheses presented by Frank Ruda in his Hegel's Rabble. Apart from studying the above-mentioned paragraphs of the Philosophy of Right, Ruda turns to Hegel's lectures from 1821/1822, where we can read "Es gibt auch reichen Pöbel [There is also the rich rabble]" (Hegel 2005, 222). Just like the poor rabble, the rich or luxury-rabble, as Ruda later calls the wealthy elite, is excluded from a society based on estates and collective labor (Ruda 2011, 12-13). But unlike the poor rabble, which is a consequence of a structural lack in the society itself, the rich rabble starts with a subjective attitude and a decision to gamble in order to join the "happy few" that can benefit from wealth without the mediation of labor (Ruda 2011, 36, 40).

The connection between the rabble at one side of the social spectrum and the rich elite at the other side can be found in Hannah's Arendt's analysis of totalitarianism. The "déclassés of all classes" are called the 'mob' or 'masses' in the Origins of Totalitarianism (Arendt 1962, 10). Just like Hegel, Arendt sees the mob as a "by-product of capitalist production," which creates both "superfluous wealth" and the "human debris (...) eliminated permanently from producing society" (Arendt 
$1962,150)$. However, unlike Hegel, for whom the two rabbles were just particularities excluded from the universal (Ruda 2011, 43-44), Arendt claims that there can be an alliance between the mob and capital. The "superfluous men" were used by "superfluous wealth" in order to establish imperialism, creating "superfluous goods" and dividing "mankind into master races and slave races." According to Arendt, "completely unprincipled power politics could not be played until a mass of people was available who were free of all principles and so large numerically that they surpassed the ability of state and society to take care of them" (Arendt 1962, 147, 151-152, 157). The two by-products of capitalist society can therefore become dangerous, because the rabble is prone to being manipulated and exploited by the elites.

More recently, the same observation can be found in Björn's Vedder's Reicher Pöbel. The author claims that the poor and the rich rabble (also called die Superreiche) acting together want to put an end to the "middle of society," which is his interpretation of the political success of today's populists (Vedder 2018, 18). The "middle" has also been fetishized by Polish liberals, whose main goal in the 1990s was to create a strong middle class in Poland. According to Tomasz Szkudlarek (2016) this goal has been accomplished and can be considered a success by the liberal elite. However, the experience of the Polish economic transformation has also produced the two "by-products" of capitalism.

\section{From 'rabble' to Meute: between potency and act}

The alliance between the capitalist elite, which in times of financial markets has even more in common with gamblers than in Hegel's times, highlights another aspect of the rabble. It is often considered a passive agent, although violence is always in potentia, in Aristotelean terms. Different words in different languages vary from a description of a social 'class without class' or simply an 'underclass' to a denomination of an angry crowd. When thinking about the Polish mottoch or English 'mob' we picture a street or another public space full of people in actu. Plebs, 'rabble' or the French populace are not that far from petit people - they are descriptive terms for the lower strata of the popular class.

In English, 'rabble' is usually used to describe a certain social status, so the violence is not in actu, Moreover, when looking at phraseology we can see the passive character of the rabble. First of all, there are expressions such as "rabble rousing" and "rabble rousers," which create an image of the rabble as being susceptible to manipulation and agitation 
by populist leaders. Similar passivity can be found in Arendt, where the mob is not only prone to being (mis)led, but will actively "shout for the 'strong man' the 'great leader' (Arendt 1962, 107). Another English expression is only used in academic discourse, yet conveys the same passivity. "Rabble management" was first used by John Irwin in The Jail. According to this theory, the "incarceration of rabble in local jails has more to do with the threat that their presence and behavior pose to moral sensibilities than it does to public safety" (Fitzpatrick, Myrstol $2011,273)$. So the penitentiary system in United States would endeavor to relocate the rabble from "respectable neighborhoods," where they are unwelcome and disturb the aesthetic taste of middle and upper class residents. In fact, the problem of homelessness is often presented not as a problem of the persons with nowhere to live, but as a nuisance in the urban landscape - an element disturbing "respectable citizens," who have to look at the rabble instead of enjoying the view. In Poland, one of the Cracow city councilors, Łukasz Wantuch, criticized volunteers who were distributing soup to the homeless in a park surrounding the old town, because "it should be a beautiful place" (Figurski, Grzesiczak 2017).

In romance languages many words for rabble are just augmentatives or diminutives of peuple, povo or gente - words referring to people in general or to the non-elites. In French there is populace, which Larousse defines as "popular strata considered with contempt" (Larousse 2019). In Portuguese there is a number of augmentatives, such as povão, meaning "a large quantity of persons" or in Brazil "the lowest social class," populacho and populaça which can also mean both 'crowd' and 'rabble', and povaréu or povoleu - depreciative terms for the underclass (Priberam 2019). The augmentatives are however less interesting than the diminutive povinho. Unlike the augmentatives, the term is not used to describe active crowds, but it is very present in Portuguese culture thanks to a caricature created in 1875 by Rafael Bordalo Pinheiro: the famous Zé Povinho. Zé is a short form of the popular name José and the caricature depicts a bearded fat man representing the Portuguese popular classes, who soon became also a symbol of national identity. The motive was very present during and after the Carnation Revolution, when many images of Zé Povinho were published in Portuguese newspapers and then depicted in a short documentary by Lauro António (Cinept 2019). Up to this day many men will wear costumes representing Zé Povinho, for example to celebrate the anniversaries of the Carnation Revolution (Jornal de Nóticias 2018).

Perhaps the most active "crowd words" are those referring to the animal kingdom. One of them is German Meute in Elias Canetti's Masse 
und Macht. The term is commonly used to describe a pack of wolves or dogs. For Canetti, a pack is an "older and more limited form of a crowd [Masse]" and the "most natural and authentic [echteste] pack" is the one that hunts. It is necessarily active, since there always has to be a direction [Gerichtetheit]. Moreover, even the etymology justifies the use of Meute in the sense of an active, primitive group of human beings: it comes from Latin movita, meaning movement (Canetti 2001, 63-64). The same origin can be found in French émeute, which used to mean "being moved emotionally" but is now used as an equivalent for riots. As for the English equivalent of Meute, the 'pack', the same form appears in German, but without the animal connotation. In fact, it can be translated precisely as 'rabble'. The word gained much media attention in 2015, when the SPD party leader called extreme right protesters "Pack und Mob" who should be locked up (Focus 2015). The term Pack was immediately "owned" by the rally that welcomed Angela Merkel in Heidenau. The placards with the slogan "Wir sind das Pack" could be seen next to "Wir sind das Volk" ones (Die Welt 2015).

Whether in potentia or in actu, violence is a necessary part of the definition, as it is the only means of expression of the rabble. It is not represented in the Parliament, not to mention the media. Unlike the financial or intellectual elite, the rabble cannot express themselves through any published material. That is why for Antonio Negri and Michael Hardt the French term jacquerie is a great example "of self-organized rebellion based on indignation" (Negri and Hardt 2009, 236). The violence of the jacquerie is usually presented as a purely destructive force, an expression of wrath without any constructive project. Being constructive is often perceived as a quality restricted to (preferably non-violent) groups sharing common interests, while the mob, for example in Arendt's writings, is a group lacking these interests and is therefore a negative phenomenon (Arendt 1962).

\section{Foule: a contagious folly}

When thinking about mottoch in its active form of a crowd, there is another important pattern which we have inherited from a $19^{\text {th }}$ century French psychologist, Gustave Le Bon. In his Psychologie des foules we can find a description of a phenomenon that may be called the "dumbing down" of the members of a crowd as a consequence of their mere participation in it (Schwab 2011, 1). Although Le Bon's theses about "losing reason" have been refuted in the field of social psychology (Reicher, Haslam 2013), they are still present in the popular worldview. According 
to Robert Nye, "collective psychology lent a certain conceptual bias to elite-mass theory that later theorists found particularly difficult to avoid" (Nye 1977, 12-13). It is certainly visible both in Arendt's and in Canetti's explanations of totalitarianism. In spite of the fact that foule is not etymologically related to folie (madness) and fou (crazy), it certainly bears resemblance to it, which may reinforce the intuition of a lack of reason produced by an aggregation of otherwise rational individuals.

Losing prestige through group-formation can be observed even in classical Greek literature. According to Justin Schwab, Penelope's suitors, despite their noble origin, are "reduced to the status of a mob by the fact of their aggregation" (Schwab 2011, 1). The word ochlos does not appear in Greek until Pindar, so Homer uses the word homilos, "together-group" to describe crowds and especially the suitors who, "in relation to Odysseus's family and estate, [...] are a ravenous horde" (Schwab $2011,40,57)$. As for the term ochlos, it could be used both in the military context of armies and soldiers and in a more political sense, as "populace, mob" (De Vivo 2006, 278). In Allan Bloom's translation of Plato's Republic it is usually translated as 'mob' (Plato 1968, 397b, 494a, $565 \mathrm{e}, 607 \mathrm{c}$ ) and in Władysław Witwicki's Polish translation it is rendered most frequently by ttum, which means simply 'crowd' (Plato 2001, $397 \mathrm{~b}, 494 \mathrm{a}, 607 \mathrm{c}$ ). The term ochlocratie was only coined later, in Middle French and then appeared as oclocrazia in modern Italian and ochlocracy in contemporary English (De Vivo 2006, 279).

In Latin, the crowd can be referred to as vulgus, a term having a class connotation, or as a more neutral turba. The latter word is associated with disorder, turmoil and therefore potential danger. According to Alexandra Sofroniew, in Rome "a large group or crowd of men was viewed as such an unpredictable and potentially hostile force that the Roman army was forbidden from marching into the city." In Cicero, we can find both terms used one after another in order indicate that "there were crowds of both high-class and low-class people." Thus, on one hand, the ideas of rabble and crowd are two different ideas, but on the other hand, any turba, or even "purely numerical" multitudo can become a mob threatening those in power, and "for the Roman elite [...] the crowd was never orderly or passive" and was very often considered dangerous (Sofroniew 2006, 30-31). In other authors, both turba and multitude can become synonyms of plebs (Connolly 2006, 85), so one can say that the act of congregating is in itself becoming-rabble.

An important metaphor in Le Bon's writings is that of contagion. This "hypnotic" phenomenon makes any act or feeling spread through the crowd, making its participants ready to sacrifice their individual 
interest in the name of the collective (Le Bon 1895, 18). Again, the contagious character of a crowd can be traced back to ancient Greece and the Plato's Republic:

'When', I said, 'many gathered together sit down in assemblies courts, theaters, army camps, or any other common meeting of a multitude [plethos], and, with a great deal of uproar, blame some of the things said or done, and praise others, both in excess, shouting and clapping; and besides, the rocks and the very place surrounding them echo and redouble the uproar of blame and praise. Now in such circumstances, as the saying goes, what do you suppose is the state of the young man's heart? Or what kind of private education will hold out for him and not be swept away by such blame and praise and go, borne by the flood, wherever it tends so that he'll say the same things are noble and base as they do, practice what they practice, and be such as they are?'.(Plato 1969, 492b-c)

Unlike determined social groups, such as classes, the mob can only act on the basis of "here and now." It is capable of erasing any prior education or attitude, but at the same time its interests, goals and any description are only valid in the particular moment and cannot be maintained beyond the actual gathering.

On a political level, the expression of this contagion can be found in Arendt's vision of imperialism which tries to "unify the people on the basis of the mob." Mass society appears when it becomes atomized, composed of lonely individuals - precisely the characteristics that appear in both Hegel's and her own definition of Pöbel or the mob. Without referring to Le Bon explicitly, she writes that the psychology of the mob is "fairly well known" (Arendt 1962, 152, 316-317, 327). This transposition of crowd psychology onto a political level can be found in many analyses, as well as in the notion of "populism" which exists in many languages and expresses the same fear of unifying the people on the basis of the mob. ${ }^{1}$

\section{Erev rav: the outside of the people}

The violence of the rabble is perceived as non-constructive, because the rabble itself lacks the identity ${ }^{2}$ that could be a starting point for a poli-

1 The problem is thoroughly analyzed by Enrnesto Laclau in his On Populist Reason.

2 Here I am using the term "identity" in a contemporary sense, as a psychological identification with a social group (Merriam-Webster 2020; Descombes

Unlike determined social groups, such as classes, the mob can only act on the basis of "here and now." It is capable of erasing any prior education or attitude, but at the same time its interests, goals and any description are only valid in the particular moment and cannot be maintained beyond the actual gathering. 
tical project. As in Hegel's Encyclopedia, the rabble is a mere aggregate of particular persons, a perfectly contingent and temporary mass of individuals whose only common denominator is being excluded from the estates. Belonging to an estate is what gives a person "substantial being" and makes them "something" (etwas) (Ruda 2011, 13). Pöbel (whether poor or rich) is defined only by negation, as an outside of the society. The same image can be found in the Hebrew erev rav, a biblical expression usually translated as "mixed multitude." In Exodus we can read: "A mixed multitude also went up with them [Israelites], along with flocks and herds, a very large number of livestock." (Exodus 12:38). One English translation, as well as the Polish ones, speak of "ethnically diverse crowd," różnoplemienny lud (people of different tribes) or wieloplemienny ttum (crowd of many tribes). David Lemler translates this literally into French as mélange multiplié (multiplied mixture) or beaucoup de mélange (a lot of mixture), but then gives equivalents of populace (rabble) and masse non identifiée (unidentified mass). In the Bible it denominates the people about whom we only know that they accompanied the Israelites, staying "at the margin" of their camp (Tamari 2014, 117).

Its liminary character can be compared to Hegel's Pöbel and to Rancières part sans part, as interpreted by Zachary Tavlin: "They have no firm place in society, they are formally excluded, though they subsist necessarily on the boundary between the inside and outside of the system" (Tavlin 2018, 13). In the late Midrashes, it is used retroactively to describe the Sin of the Calf: it was the erev rav, the strangers, who led the people of Israel to commit the idolatry (which the "chosen people" would not have committed otherwise). In the Middle Ages, especially in the Zohar, the activity of erev rav was extended to almost all human history, including Paradise (erev rav was in the snake's poison that infected Eve). The concept persisted among Jewish diaspora and according to Paweł Maciejko, "the dichotomy between the true Israel and the mixed multitude constituted the major conceptual axis of the theological controversies that tore apart eighteenth-century Judaism" (Maciejko 2011, 4-6). More recently the term has started to be used in explicitly racist discourse by religious Zionists (Tamari 2014, 117-118). In the imaginary of erev rav it is the metaphor of infiltration which gives the term its political, xenophobic dimension. It is a dangerous element coming from the outside, which is integrated in the society, but at the same time stays separate and will forever remain a foreign element: it is

2013, 20), which I understand as a common name and usually a set of characteristics. 
sometimes called "the enemy within." Being erev rav is perceived as hereditary and it can be recognized by some distinctive features, which makes both the nation of Israel and the erev rav quasi-biological determinations (Tamari, 119-125). This is of course not new, since the differences between peoples have always been perceived not only in political terms, but also as a "natural reality" - ethnos and especially genos being perceived in terms of geography and extended family (Cassin, Crépon and Moatti 2014, 752, 758).

Another metaphor used in the context of erev rav is that of dirt that needs to be cleaned (Tamari 2014, 119-129). This discourse is obviously racist, especially in the Foucauldian sense of the other race that is "not the race that came from elsewhere or that was, for a time, triumphant and dominant, but that it is a race that is permanently, ceaselessly infiltrating the social body, or which is, rather, constantly being re-created in and by the social fabric" (Foucault 2003, 61), just like rabble is re-created in society. The same imaginary can be found in the English terms scum or vermin used against Polish immigrants (Rettman 2016). "Contorred, insectlike individuals who have fallen from grace and must be expunged" can also be found in Chinese propaganda posters, which according to Haun Saussy depict human characters in three possible ways: as "exalted individuality (the status of leaders), exalted generality (the personifications), and the debased individuality (the criminals)" (Saussy 2006, 262). Outcasts are often seen as potential criminals. For example the Dutch term crapuul in an article about the $19^{\text {th }}$ century socialist Jacob Kats, has been translated as 'rabble' into English and as canailles (scoundrels) into French (Bussel and Van Oostveldt 2012). The last term refers explicitly to minor or potential criminals and is not far from racaille, an even more derogatory term notoriously used by Nicolas Sarkozy in 2005 to describe the protesters from the popular districts (Pulham 2005).

Slavoj Žižek sees today's rabble in "illegal immigrants, slum-dwellers, refugees etc.," since they are "denied even the right to be exploited through work" (Žižek 2012, 440). The category of immigrants shares the undetermined character of the rabble, since it applies to the liminary "part of no part" of the society and it denominates a "crowd of many tribes" that do not share any positive descriptor. At the same time, in spite of the definition, being an immigrant is considered to be hereditary, and just like erev rav, immigrants remain separated within the society. That is why we use the expression "second-generation immigrant" which is used to describe persons who are in no sense migrants, since at no point in their lifetime have they migrated to another country. In the 
Polish context, since other "tribes" remain outside, the rabble understood as the strangers within can appear in the form of foreign agents (especially Jewish or German), or as descendants of peasants, who are seen as incompetent in terms of democracy, as in a recent interview with famous Polish actor Jerzy Stuhr, who called the ruling party supporters "descendants of feudal peasants" (Lis and Stuhr 2019). The rural origin of the rabble can also be observed in the above-described image of Zé Povinho.

Whether it is rural or foreign origin that makes a person an outsider and therefore a potential member of the rabble, an important trait is ignorance of the rules of what Italians call civiltà. The word means both "civilization" and "civility": neutral citizenship and so-called "good manners" (Pons 2014, 139-140). A newcomer to the city-state is someone who does not know its rules and this shows in their behavior and mannerisms. In Polish there is an expression describing someone of rural origin which can be translated as "there is hay sticking out of his shoes" and the adjective "vulgar," as well as its equivalents in many languages, is usually used to describe inappropriate and uncivil behavior. Being vulgar is often depicted as an act of voluntarily excluding oneself from being taken seriously in the public debate. Civility is considered a crucial feature of a good politician and often receives more media attention than actual political decisions, even as important as military interventions (Feinberg, Shirazi and Johnson 2018). Civility is supposed to be a common denominator of the elites and the common citizens, but it excludes the uncivil and the vulgar - the rabble. So there is an important difference between the terms "civil society" and "the people" (and their equivalents in other languages). Although both can refer to the totality of a society and include all its members, they can also exclude. And while "the people" tends to exclude the elites, but can include the rabble, "civil society" tends to exclude the rabble and include the elites. In fact, the latter can be even considered to have more civiltà than other members of society. Of course, any term can be used so as to exclude the rabble and the meanings change depending on policy and historical factors (Cassin, Crépon and Moatti 2014, 762-763; Agamben 2000, 34-35).

\section{Undetermined plurality}

The vision of the rabble as a highly atomized group of individuals is one of two at first sight contradictory images which appear throughout different theories. Hannah Arendt, especially in the third part of her Origins of Totalitarianism, writes repeatedly that the mob and the masses 
lack any common interest, or "that specific class articulateness which is expressed in determined, limited, and obtainable goals" (Arendt 1962, 311). We can find the same perspective in Hegel, for whom vulgus is a mere "aggregate of private persons" (Hegel 2008, 243) and the same applies both to the poor and the rich rabble (Ruda 2011,39). The same image, but referring to a wider group called the "masses" can be found in Werner Sombart, for whom Masse is "the unrelated, amorphous agglomeration of population in the modern metropolises, which lacking all internal articulation and abandoned by the spirit, that is, by God, form an inert throng of pure units" (Sombart 1924, 99). So on one hand we have a distributive set of individuals about whom we know nothing, except perhaps for the fact that they come "from many different tribes" (but not ours).

On the other hand, there are images of the crowds acting as an irrational beast, which devours the reason of its members and is a threat to the "middle of society" (Reich 2018,18 ). There is a common identity to this image even if the authors deny it: the crowds are homogenous and therefore dangerous, both physically and politically, since it is on the basis of the masses that totalitarianisms are formed. In this vision the lack of identity is attributed mostly to the members of the mob: they lose their individuality and identity to participate in the temporary movement of a crowd.

Not sharing a common identity, as well as losing one's own particular identity in a homogenous crowd is generally considered undesirable, if not dangerous. One of the answers can be found in the concept of "diversity." The term's particular career in American discourse has been traced by Jeff Chang in his book We Gon' Be Alright. It entered corporations and colleges, who would even appoint "chief diversity officers" and use diversity as a criterion in official rankings. It started to be treated as an end in itself and became "good business," especially since it removed equity or historical justice from the debate. Chang writes that "diversity allows whites to remove themselves while requiring the Other to continue performing for them" and that it led to new policies. For example, affirmative action has been replaced by a system which privileged the top ten per cent of every high school, which only worked when there was a significant resegregation on the school level. As a result, "most universities never returned to the level of diversity or equity they had attained before affirmative action programs were gutted" (Chang 2016, 17, 28-29).

In fact, the idea behind 'diversity' can be seen as the opposite of the potential of the rabble. Whether erev rav, Pöbel or ochlos, every rabble 
is more or less undetermined. Being depicted mainly in negative terms, as an outside of the social order, the different rabbles usually lack positive characteristics, whereas the policies of diversity always rely on a closed catalogue of determined identities. The undetermined plurality of the rabble escapes diversity and that is why it can be seen as a revolutionary project, according to Negri's and Hardt definition, which is based on their interpretation of radical feminism, which "seeks an abolition of identity itself." The politics of "disidentification" bears a revolutionary potential illustrated by the term "queer" - an identity of non-identity. In this sense, the rabble is queer, since it disidentifies its members and escapes any stable group identification. The rabble is also not far from the "multitude of the poor" considered by the same authors a revolutionary agent (Negri and Hardt 2009, 3-40, 334-335). In an older text, Negri writes explicitly that the multitude needs to be considered not under a unifying concept (e.g. that of the people), which forms some transcendental identity, but on the plane of immanence, as "unrepresentable singularities" (Negri 2002). Here, identity can be understood in a broader sense surpassing the social group context mentioned above. The term "queer" can be understood as a refusal to answer the basic question "Who am I?" (Descombes 2013, 17) at all, since any possible answer is always determined by existing social order. Participating and "losing oneself" in the mob can be understood as going further and refusing to even ask the question, since any attempt to name a crowd or its participants is in itself transcendental.

\section{Conclusion}

As we have seen, the rabble and the people, as well as the rabble and the mob (or the crowd), are treated as one in many languages and this can be seen as a revolutionary potential of the rabble. The crowd is always in movement, in becoming. Both the crowd itself and its members, as part of the crowd, can only have an identity of here and now. It can be considered the "people-as-event" in Rosanvallon's terms (Jonsson 2006, 55-56). The rabble is considered dangerous by the conservative elite when it starts to "invade" their space. Ortega y Gasset and other elitists had nothing against the unprivileged as long as they could reduce them to res extensae (Resina 2006, 227) - docile and occupying their position (out of sight).

The attempts to transform revolutionary crowds, such as American Occupy, Spanish Indignados or Polish Czarny Protest, into traditional 
political movements based on common identities are very often disappointing. Like after the Tennis Court Oath, "once the revolutionary event passes, the two bodies separate. The people as a principle of sovereignty no longer finds any correspondence in reality; and the people as a sociological reality recedes back into invisibility, into numbers." And then the reaction is to separate the rabble and the people: the elites, like Adolphe Thiers after the revolution of 1848, will want to exclude the masses (la multitude) of vagabonds and convince the public that they are something different from the people (Jonsson 2006, 56, 71). In such a discourse, the legitimate people becomes an abstract term referring to the invisible and obedient "civil society" and excluding the dangerous rabble who could start another uprising. So the mob is an event, a jacquerie, a rebellion which is not organized by a trade union or other preexisting social movement. It is the social movement itself, "self-organizedm," happening spontaneously, not as a result of a project. And the rabble, an undetermined plurality without any stable identity apart of the fact of being excluded from the dominant mainstream "middle" of the society, is the basis of every revolutionary crowd. Perhaps it is the fact of distinguishing the rabble and the people is that leads to the constant alienation of those who were supposed to represent the latter. 


\section{References}

Agamben, Giorgio. 2000. Means without End. Notes on Politics. Translated by Vincenzo Binetti and Cesare Casarino. Minneapolis/London: University of Minnesota Press.

Airaksinen, Timo. 1985. "Hegel on Poverty and Violence." In Economic Justice: Private Rights and Public Responsibilities. Edited by Kenneth Kipnis and Diana T. Meyers. Lanham: Rowman \& Littlefield.

Arendt, Hannah. 1962. The Origins of Totalitarianism. Cleveland/New York: Meridian Books.

Canetti, Elias. 2001. Masse und Macht. Wesentliche Zusammenhänge zum Verständnis unseres Zeitalters. Berlin: Fischer Taschenbuch Verlag.

Cassin, Barbara, Crépon, Marc, Moatti Claudia 2014. "People/Race/ Nation." In Dictionary of Untranslatables. A Philosophical Lexicon. Edited by Barbara Cassin. Translation edited by Emily Apter, Jacques Lezra, and Michael Wood. Princeton and Oxford: Princeton University Press.

Cassin, Barbara. 2014. "Énergie des intraduisibles - La traduction comme paradigme pour des sciences humaines." In Philosopher en langues. Les intraduisibles en traduction. Edited by Barbara Cassin. Paris : Éditions Rue d'Ulm.

Chang, Jeff. 2016. We Gon' Be Alright. New York: Picador.

Cinept. 2019. "O Zé-Povinho na Revolução (1978)." Cinema português. http://www.cinept.ubi.pt/pt/filme/3336/O+Z\%C3\%A9-Povinho+ na+Revolu\%C3\%A7\%C3\%A3o.

Connolly, Joy. 2006. "Crowd Politics: The Myth of the 'Populus Romanus." In Crowds. Edited by Jeffrey T. Schnapp and Matthew Tiews. Stanford: Stanford University Press.

De Vivo, Sebastian. 2006. “'Ochlos': Ancient Greek.” In Crowds. Edited by Jeffrey T. Schnapp and Matthew Tiews. Stanford: Stanford University Press.

Descombes, Vincent. 2013. Rozterki Tożsamości.Translated by Michał Krzykawski. Warszawa: Kurhaus.

Die Welt. 2015. “'Wir sind das Pack' - Merkel wird ausgebuht". Die Welt, 26 August. https://www.welt.de/politik/deutschland/ article145659437/Wir-sind-das-Pack-Merkel-wird-ausgebuht.html.

Dudenredaktion (o. J.). 2019. "Pöbel." https://www.duden.de/rechtschreibung/Poebel.

"Exodus." 2019. New American Standard Bible. https://www.bible.com/ bible/100/EXO.12.38.NASB. 
Feinberg, Ashley, Shirazi, Nima and Johnson, Adam. 2018. "The Civility Fetish." Citations Needed. Episode 40. https://citationsneeded. libsyn.com/episode-40-the-civility-fetish\#.

Figurski, Paweł and Grzesiczak, Łukasz. 2017. Radny Wantuch przeciw pomaganiu bezdomnym na Plantach. "Chciałbym, by były piękne." Gazeta Wyborcza. 20 April. https://krakow.wyborcza.pl/krakow/7,44425,21664885, radny-wantuch-przeciw-pomaganiu-bezdomnym-na-plantach-chcialbym.html.

Fitzpatrick, Kevin and Myrstol, Brad. 2011. “The Jailing of America's Homeless: Evaluating the Rabble Management Thesis." Crime \& Deliquency $57(2)$.

Focus. 2015. "Gabriel attackiert Fremdenhasser: 'Pack, das eingesperrt werden muss" FOCUS online, 24 August. https:/www.focus.de/ politik/videos/spd-chef-spricht-klartext-gabriel-attackiert-rechtefluechtlingshetzer-pack-und-mob-das-eingesperrt-werden-muss_ id_4899288.html.

Foucault, Michel. 2003. "Society Must Be Defended". Lectures at the Collège de France 1975-76. Translated by David Macey. New York: Picador.

Hegel, Georg Wilhelm Friedrich. 2005. Die Philosophie des Recht. Vorlesungen von 1821/22. Frankfurt: Suhrkamp.

- 2008. Outlines of the Philosophy of Right. Translated by Thomas Malcolm Knox. Oxford/New York: Oxford University Press.

Jonsson, Stefan. 2006. "The Invention of the Masses: The Crowd in French Culture from the Revolution to the Commune." In Crowds. Edited by Jeffrey T. Schnapp and Matthew Tiews. Stanford: Stanford University Press.

Jornal de Nóticias. 2018. "O Zé Povinho saiu à rua com cravos em Lisboa e no Porto.” Jornal de Nóticias. 25 April. https://www.jn.pt/ nacionalgalerias/o-ze-povinho-e-outros-milhares-sairam-a-rua-comcravos-em-lisboa-9285466.html.

Kuczok, Wojciech. 2019. “Oto nadchodzi polski paździerznik.” Gazeta Wyborcza. 29 September. http://wyborcza.pl/7,154903,25249829,wojciechkuczok-oto-nadchodzi-polski-pazdzierznik.html.

Laclau, Ernesto. 2005. On Populist Reason. London/New York: Verso.

Larousse. 2019. "Populace." In Dictionnaire de la langue française. https:// www.larousse.fr/dictionnaires/francais/populace/62609?q=populace\#61905.

Le Bon, Gustave. 1895. Psychologie des foules. Paris: Félix Alcan.

Lis, Tomasz and Stuhr, Jerzy. 2019. "Jerzy Stuhr: Moje największe sympatie budzi odradzająca się lewica.” https:/www.youtube.com/wat- 
ch?v=rvK6dlJzV68.

Luther, Timothy C. 2009. Hegel's Critique of Modernity: Reconciling Individual Freedom and the Community. Lanham: Lexington Books.

Maciejko, Paweł. 2011. The Mixed Multitude. Philadelphia: University of Pennsylvania Press.

Mattingly, Harold B. 1997. "The date and purpose of the pseudo-Xenophon constitution of Athens." Classical Quarterly 47.

Merriam-Webster. 2020. "Identity." In Merriam-Webster.com Dictionary. https://www.merriam-webster.com/dictionary/identity.

Negri, Antonio. 2002. "Pour une définition ontologique de la multitude." Multitudes 9(2). English translation by Arianna Bove : https://www. multitudes.net/Towards-an-Ontological-Definition/.

Negri, Antonio and Hardt, Michael. 2009. Commonwealth. Cambridge: Harvard University Press.

Nogaś, Michał and Kołodziejczyk, Marcin. 2019. "Kim są bohaterowie Prymitywu?" Gazeta Wyborcza. 16 Spetember. http://wyborcza. $\mathrm{pl} / 7,75517,25186895$, bohaterowie-prymitywu-to-kto-kolodziejczyk-to-sa-suwereni.html.

Nye, Robert A. 1977. The anti-democratic sources of elite theory: Pareto, Mosca, Michels. Beverly Hills: Sage Press.

Plato. 1969. The Republic. Translated by Allan Bloom. New York: Harper Collins.

2001. Państwo. Translated by Władysław Witwicki. Kęty: Antyk.

Priberam. 2019. Dicionário Priberam da Lingua Portuguesa. https:// dicionario.priberam.org/.

Pons, Alain. 2014. "Civiltà." In Dictionary of Untranslatables. A Philosophical Lexicon. Edited by Barbara Cassin. Translation edited by Emily Apter, Jacques Lezra, and Michael Wood. Princeton and Oxford: Princeton University Press.

Pulham, Sheila. 2005. "Inflammatory Language." The Guardian. 8 November. https://www.theguardian.com/news/blog/2005/nov/08/ inflammatoryla.

Resina, Joan Ramon. 2006. "From Crowd Psychology to Racial Hygiene: The Medicalization of Reaction and the New Spain." In Crowds. Edited by Jeffrey T. Schnapp and Matthew Tiews. Stanford: Stanford University Press.

Rettman, Andrew. 2016. "Poles and Muslims insulted after Brexit vote." EUobserver. 27 June. https://euobserver.com/justice/134044.

Ruda, Frank. 2011. Hegel's Rabble. An Investigation into Hegel's Philosophy of Right. London / New York: Continuum.

Saussy, Haun. 2006. "Crowds, Number, and Mass in China.” In Crowds. 
Edited by Jeffrey T. Schnapp and Matthew Tiews. Stanford: Stanford University Press.

Schwab, Justin Jon. 2011. The Birth of the Mob: Representations of Crowds in Archaic and Classical Greek Literature [PhD Thesis]. Berkeley: University of California. https://escholarship.org/uc/item/7hf7312f.

Sigov, Konstantin. 2014. "Ukrainien - Nous adressant à l'autre, devenons nous-même: le défi du Vocabulaire européen en Ukraine." Translated by Pierre Defontaines. In Philosopher en langues. Les intraduisibles en traduction. Edited by Barbara Cassin. Paris: Éditions Rue d'Ulm.

Smoleński, Paweł. 2019. "Narody, które się mordowały. Prestiżowy laur za Naszą wojnę dla Włodzimierza Borodzieja i Macieja Górnego.” Gazeta Wyborcza. 7 October. http://wyborcza.pl/alehistoria 17,121681,25265887, narody-ktore-sie-mordowaly-prestizowy-laurza-nasza-wojne.html.

Sofroniew, Alexandra Katherina T. 2006. “'Turba’: Latin.” In Crowds. Edited by Jeffrey T. Schnapp and Matthew Tiews. Stanford: Stanford University Press.

Sombart, Werner. 1924. Der proletarische Sozialismus ('Marxismus'): 2 Bde. Jena: G. Fischer.

Szkudlarek, Tomasz et al. 2016. "Podziały klasowe i demokracja” https:// www.youtube.com/watch? $v=\mathrm{tm} Y \mathrm{Hk}$-ay $4 \mathrm{Yw}$

Tamari, Assaf. "Erev rav (erev-rav).” Adapted into French by David Lemler. In Philosopher en langues. Les intraduisibles en traduction. Edited by Barbara Cassin. Paris: Éditions Rue d'Ulm.

Tavlin, Zachary. 2018. "The real of the rabble: Žižek and the historical truth of the Hegelo-Lacanian dialectic." Contemporary Philosophy Review 51.

Vedder, Björn. 2018. Reicher Pöbel. Über die Monster des Kapitalismus. Marburg: Büchner Verlag.

Žižek, Slavoj. 2012. Less than Nothing. Hegel and the Shadow of Dialectical Materialism. London/New York: Verso. 
BARBARA BRZEZICKA - graduated in Romance Philology and Philosophy at the University of Gdańsk, where she also did her PhD thesis on translation of philosophical texts. She is an assistant professor at the Institute of Romance Philology (UG) and a member of the editorial board in Czas Kultury. Her research focuses on translation studies, $20^{\text {th }}$ century French philosophy and cultural linguistics. Full academic profile: https://repozytorium.bg.ug.edu.pl/info.seam?id=UOG2099124aff1b4bef97c53ea313fc7d79\&affil=\&lang=en

\section{Address:}

Instytut Filologii Romańskiej

Uniwersytet Gdański

Wita Stwosza 51

80-312 Gdańsk

email: barbara.brzezicka@ug.edu.pl

Citation: Brzezicka, Barbara. 2020. "The Rabbles, the Peoples and the Crowds: a Lexical Study." Praktyka Teoretyczna 2(36): 15-35.

DOI:10.14746/prt2020.2.2

\section{Autor: Barbara Brzezicka}

Tytuł: Językowe obrazy motłochów, ludów i tłumów w filozofii i poza nią

Abstrakt: Motłoch, rozumiany jako możliwe zagrożenie na praworządności lub też jako grupa, której nie należą się prawa obywatelskie, jest pojęciem obecnym w wielu językach. Jednak każde słowo niesie ze sobą inne znaczenie, które można nazwać nieprzekładalną resztą. Niniejszy artykuł stanowi próbę przedstawienia konceptualnej mnogości motłochu w sposób inspirowany leksykonem nieprzekładalników filozoficznych pod redakcją Barbary Cassin (Vocabulaire européen des philosophies). W treści wyróżnione zostały pewne schematy, które można zaobserwować w różnych językach i które mogą stanowić punkt wyjścia do dalszej analizy filozoficznej. Artykuł ten nie jest ani wyczerpującą prezentacją wielojęzycznej semantyki motłochu, ani filozoficzną analizą wykluczenia społecznego, a raczej próbą ukazania wielości znaczeń i tego, jak mogą one kształtować i inspirować filozoficzną refleksję.

Słowa kluczowe: motłoch, lud, nieprzekładalniki, demokracja, wykluczenie społeczne 